\title{
ANALISIS PENDAPATAN DAN BREAK EVEN POINT (BEP) USAHATANI BAWANG MERAH DI DESA LAPANDEWA KAINDEA KECAMATAN LAPANDEWA KABUPATEN BUTON SELATAN
}

\author{
La Ode Muhammad Mustari \\ Program Studi Agribisnis, Fakultas Pertanian \\ Universitas Muhammadiyah Buton \\ J1. Betoambari No. 36 Baubau \\ E-mail: laodemustari2019@gmail.com
}

\begin{abstract}
This study aims to determine how much the average income earned by farmers from shallot farming in Lapandewa Kaindea Village, Lapandewa Sub-district, South Buton Regency and how much Break Even Point (BEP) received by onion farmers in Lapandewa Kaindea Village, Lapandewa Sub-district, South Buton Regency. This study was carried out in Lapandewa Kaindea Village, Lapandewa Sub-district, South Buton Regency for two months from June to July 2017. The population of this research is the existing cashew farmers. The research sample was 32 cashew farmers. Data was collected through interviews using questionnaires and data analysis using cost and revenue analysis. The results showed that the average income earned by farmers in conducting onion farming activities with an area of $0.1-0.25$ ha, an average land area of 0.14 ha with an average income of IDR 3.282.000, and a Break Even Point (BEP) IDR 1.541.000. Recommendations local governments, particularly at the district level need to establish regulations relating to the onion marketing system, especially the basic pricing.
\end{abstract}

Keywords: Income, Break Event Point (BEP), Onions

\begin{abstract}
Abstrak
Penelitian ini bertujuan untuk mengetahui berapa besar rata-rata pendapatan yang di peroleh petani dari usahatani bawang merah di Desa Lapandewa Kaindea Kecamatan Lapandewa Kabupaten Buton Selatan dan Berapa besar Break Event Point (BEP) yang diterima petani bawang merah di Desa Lapandewa Kaindea Kecamatan Lapandewa Kabupaten Buton Selatan Penelitian ini di laksanakan di Desa Lapandewa Kaindea Kecamatan Lapandewa Kabupaten Buton Selatan selama dua bulan dari bulan Juni sampai bulan Juli 2017. Populasi dari penelitian ini adalah petani jambu mete yang ada, sampel penelitian mengambil petani jambu mete berjumlah 32 orang. Data dikumpulkan melalui wawancara dengan menggunakan daftar pertanyaan (quesioner) dan análisis data menggunakan analisis biaya dan penerimaan. Hasil penelitian menunjukan bahwa rata-rata pendapatan yang diperoleh petani dalam melakukan kegiatan usahatani bawang merah dengan luas 0,1 - 0,25 ha rata-rata luas lahan 0,14 ha dengan rata-rata pendapatan Rp 3.282.000, - dan Break Event Point (BEP) Rp 1.541.000, -.
\end{abstract}


Rekomendasi Pemerintah daerah terutama ditingkat kabupaten perlu menetapkan peraturan-peraturan yang berhubungan dengan sistem pemasaran bawang merah terutama penetapan harga dasar.

Kata Kunci: Pendapatan, Break Event Point (BEP), Bawang Merah

\section{PENDAHULUAN}

\subsection{Latar Belakang}

Pembangunan di sektor pertanian dengan pola pendekatan agribisnis mempunyai peran penting di dalam perekonomian Indonesia, dimana kurang lebih 30\% produk Indonesia berasal dari sektor agribisnis. Dalam pengembangan agribisnis khususnya Hortikultura, dengan melalui pendekatan Agribisnis bertujuan memanfaatkan sumber daya secara optimal (Redaksi AgroMedia, 2008). Dari berbagai usaha yang ditawarkan di sektor Agribisnis tersebut, salah satunya adalah sektor Agribisnis cabai. Bertanam cabai sangat menarik bagi investor, terutama kalangan masyarakat yang terkena PHK akibat krisis moneter (Redaksi Agromedia, 2008). Dari berbagai jenis sayuran dan buah - buahan, cabai dinilai sebagai produk yang mempunyai harga paling tinggi dan umurnya tergolong genjah sehingga modal cepat kembali. Budidaya cabai tergolong berisiko tinggi. Namun, risiko tersebut dibayar seimbang dengan keuntungan yang dijanjikan. Karena itu, strategi dan pengetahuan teknis dan lapangan menjadi hal yang sangat penting untuk dikuasai guna mencapai hasil yang maksimal dengan menekan resiko -resiko tersebut (Rukmana, 2002).

Usaha tani adalah ilmu yang mempelajari bagaimana seseorang mengalokasikan sumber daya yang ada secara efektif dan efesien untuk memperoleh keuntungan yang tinggi pada waktu tertentu. Dikatakan efektif bila petani atau produsen dapat mengalokasikan sumber daya yang mereka miliki sebaik - baiknya, dan dapat dikatakan efesien bila pemanfaatan sumberdaya tersebut mengeluarkan output yang melebihi masukan input (Soekartawi, dalam Agustina, 2011). Efisiensi usahatani dapat diukur dengan cara menghitung efisiensi teknis, efisiensi harga dan efisiensi ekonomis. Ketiga macam efisiensi ini penting untuk diketahui dan diraih oleh petani bila ia menginginkan keuntungan yang sebesar - besarnya. Umumnya memang petani tidak mempunyai catatan usahatani (farm recording), sehingga sulit bagi petani untuk melakukan analisis usahataninya (Soekartawi, 1995).

Petani akan lebih semangat dalam berusahatani bila dalam perhitungan biaya yang selama proses produksi dengan hasil yang diperoleh memberikan keuntungan yang cukup besar bagi petani. Di dalam ekonomi produksi pertanian lebih ditekan pada penggunaan produksi secara efisien untuk meningkatkan keuntungan usahatani. Peningkatan produktivitas cabai merah besar akan memberikan keuntungan/pendapatan maksimal usahatani bawang merah. Bawang merah merupakan salah satu tanaman holtikultura yang digunakan sebagai salah satu bahan yang tidak dapat dipisahkan dari masakan makanan sehari-hari seluruh masyarakat Indonesia. Bawang merah merupakan salah satu komoditas sayuran yang memiliki nilai ekonomis tinggi, baik ditinjau dari sisi pemenuhan konsumsi nasional, sumber penghasilan petani, maupun potensinya sebagai penghasil devisa negara. 
Produksi bawang merah sampai saat ini masih terpusat di beberapa kabupaten di Jawa yaitu Kuningan, Cirebon, Brebes, Tegal, Pemalang, Bantul, Nganjuk, dan Probolinggo. Berdasarkan data dari Ditjen Hortikultura, Kementerian Pertanian, permintaan bawang merah secara nasional cenderung meningkat dari tahun ke tahun, begitu pula produksi bawang merah. Pada tahun 2007 misalnya, permintaan bawang merah sebesar 909.853 ton dengan produksi 807.000 ton, tahun 2008 permintaan meningkat menjadi 934.301 ton dengan produksi 855.000 ton. Pada tahun 2009, kebutuhan bawang merah di Indonesia mencapai 936.103 ton dengan produksi 965.164 ton dan meningkat pada tahun 2010 menjadi 976.284 ton dengan produksi 1.048.228 ton. Penurunan produksi terjadi pada tahun 2011 yaitu produksi sebesar 893.124 ton. Peningkatan produksi bawang merah diprediksi terjadi pada tahun 2012 menjadi 960.179 ton (Ditjen Holtikultura, 2011).

Tingkat permintaan dan kebutuhan konsumsi bawang merah yang tinggi menjadikan komoditas ini menguntungkan jika diusahakan. Konsumsi bawang merah di Indonesia per kapita per tahun mencapai 4.56 kilogram atau 0.38 kilogram per kapita per bulan. Tingginya permintaan bawang merah yang terus meningkat tidak hanya terjadi di pasar dalam negeri, tetapi berpeluang juga untuk ekspor (Ditjen Holtikultura, 2004).

Salah satu komoditi andalan Sulawesi Tenggara adalah Bawang Merah. Komoditi ini termasuk komoditi yang memiliki potensi pasar yang cukup baik untuk terus dikembangkan. Bawang merah (Allium ascalonicum L.) adalah salah satu komoditas hortikultura, biasa digunakan sebagai penyedap masakan, bahan baku industri makanan. Selain itu, bawang merah merupakan sumber vitamin B, C, kalium, fosfor dan mineral. Bawang merah varietas lembah Palu yang dikenal luas sebagai bawang goreng merupakan salah satu komoditas pertanian strategis Sulawesi Tenggara khususnya Kabupaten Buton Selatan dengan tingkat produktivitas yang masih rendah. Walaupun varietas ini produktivitasnya relatif rendah dibandingkan dengan varietas bawang merah lainnya, tetapi karena varietas ini memiliki citarasa yang baik, harum, gurih, garing dan dapat disimpan lama. Para petani tetap memilih varietas ini sebagai salah satu komoditi utama dalam usahatani mereka bahkan karena keunikan bawang goreng ini telah menjadi "brand lokal" Kabupaten Buton Selatan. Produktivitas rata-rata varietas ini dengan teknonologi petani berkisar antara 4-5 ton perhektar, sedangkan produktivitas bawang merah lainnya berkisar 7,3 ton perhektar (BPS, 2016). Berbagai hasil penelitian mengenai perbaikan cara bercocok tanam menunjukkan bahwa varietas ini memiliki potensi produksi genetik antara 11 - 13 ton/ha (Thaha, 2012). Ini berarti masih ada harapan untuk meningkatkan pendapatan petani bawang merah melalui perbaikan teknologi budidaya dan pengaturan waktu tanam untuk menghidari terjadinya overproduksi yang berakibat jatuhnya harga bawang merah di pasaran.

Besarnya produksi dan produktivitasnya bawang merah dapat dilihat pada Tabel 1. Produktivitas bawang merah di Kabupaten Buton Selatan yang di tunjukkan pada tabel 1 mengalami fluktuasi. Pada saat ini perkembangan bawang merah di Kecamatan Lapandewa terus dikembangkan, mengingat varietas ini termaksud varietas unggulan. Luas Panen, produksi, dan produktivitas tanaman bawang merah yang ada di Kecamatan Utara terlihat pada Tabel 1.

Tabel 1. Luas tanam, luas panen dan produksi bawang merah tahun 2014 - 2016 di Kecamatan Lapandewa Kabupaten Buton Selatan 


\begin{tabular}{llll}
\hline \multicolumn{1}{c}{ Tahun } & Luas Tanam (Ha) & $\begin{array}{c}\text { Luas Panen } \\
(\text { Ha) }\end{array}$ & Produksi (Ton) \\
\hline Tahun 2014 & 20 & 10 & 191 \\
\hline Tahun 2015 & 14 & 11 & 70 \\
\hline Tahun 2016*) & 24 & 13 & 120 \\
\hline
\end{tabular}

Sumber Data: Buton dalam Angka, 2016

*) Dinas Pertanian Buton Selatan, 2017

Tabel 1 di atas tersebut menunjukkan bahwa produksi bawang merah dari tahun 2015 sampai dengan 2016 mengalami peningkatan hal ini disebabkan adanya pola tanam masyarakat yang teratur dan benih bawang yang unggul serta iklim yang bersahabat. Disamping itu pula Kecamatan Lapandewa mempunyai potensi pengembangan bawang merah yang di plot sebagai kawasan bawang merah dengan lahan kurang lebih $300 \mathrm{Ha}$. Jika dimanfaatkan maka diperkirakan akan menghasilkan produksi 1.500 Ton dengan rata-rata produksi perhektar $5-6$ ton/ha.

Hasil observasi awal menunjukan bahwa masih adanya serangan penganggu tanaman, belum optimalnya sarana produksi (benih), belum optimalnya petugas dalam memberikan penyuluhan dan kurangnya kesadaran petani dalam memasarkan hasil pertanian. Produksi yang tinggi dari hasil yang diperoleh para petani mempunyai alternatif untuk memasarkan hasil produksinya seperti para pedagang pengumpul. Namun diharapkan petani mampu membaca situasi agar produktivitas yang diperoleh memberikan kontribusi bagi pendapatan petani.

Berdasarkan paparan yang dikemukakan di atas hal penting yang perlu diperhatikan antara kenyataan (masalah) diatas dan harapan, sehingga penulis tertarik menggangkat judul Analisis pendapatan dan Break Event Point (BEP) usahatani bawang merah di Desa Lapendewa Kaindea Kecamatan Lapandewa Kabupaten Buton Selatan.

\subsection{Rumusan Masalah}

Berdasarkan uraian yang dikemukakan pada latar belakang diidentifikasikan suatu permasalahan:

1. Berapa pendapatan yang diperoleh dari usahatani bawang merah di Desa Lapendewa Kaindea Kecamatan Lapandewa Kabupaten Buton Selatan.

2. Berapa Break Event Point atau tidak untung dan tidak rugi Penerimaan yang diperoleh petani pada usahatani usahatani bawang merah di Desa Lapendewa Kaindea Kecamatan Lapandewa Kabupaten Buton Selatan.

\subsection{Tujuan Penelitian}

Penelitian ini bertujuan : 
1. Untuk mengetahui pendapatan yang diperoleh dari usahatani usahatani bawang merah di Desa Lapendewa Kaindea Kecamatan Lapandewa Kabupaten Buton Selatan.

2. Untuk mengetahui berapa Break Event Point atau tidak untung dan tidak rugi penerimaan yang diperoleh petani pada usahatani usahatani bawang merah di Desa Lapendewa Kaindea Kecamatan Lapandewa Kabupaten Buton Selatan.

\subsection{Kegunaan Penelitian}

1. Hasil penelitian diharapkan dapat memberikan sumbangan pemikiran bagi petani bawang merah dalam rangka memberdayakan kemampuan faktor-faktor input agribisnis dalam mempengaruhi produksi usahatani bawang merah.

2. Menjadi bahan masukan bagi pengambil kebijakan, kalangan swasta dan usahawan dalam upaya peningkatan kemampuan faktor-faktor input agribisnis dalam mempengaruhi tingkat produksi usahatani bawang merah.

3. Hasil penelitian ini di harapkan dapat menjadi bahan informasi bagi penelitian yang lain, tentang pemberdayaan faktor-faktor input dalam mempengaruhi tingkat produksi usahatani bawang merah di Lapendewa Kaindea Kecamatan Lapandewa Kabupaten Buton Selatan.

\section{TINJAUAN PUSTAKA}

\subsection{Budidya Bawang Merah}

Cara bertanam Bawang merah organik pada dasarnya tidak berbeda dengan bertanam padi secara konvensional. Perbedaannya hanyalah pada pemilihan varietas dan penggunaan pupuk dasar. Pertanian organik biasanya diawali dengan pemilihan bibit atau benih tanaman non hibrida. Selain untuk mempertahankan keanekaragaman hayati, bibit non hibrida sendiri secara teknis memang memungkinkan untuk ditanam secara organik. Ini dikarenakan bibit non hibrida dapat hidup dan berproduksi optimal pada kondisi yang alami. Sementara bibit atau benih hibrida biasanya dikondisikan untuk dibudidayakan secara non-organik, seperti harus menggunakan pupuk kimia atau pemberantasan hanya dengan pestisida kimia. Untuk lebih jelasnya berikut diulas tentang cara bertanam adalah sebagai berikut:

1. Pemilihan varietas

2. Pembenihan yang terdiri dari seleksi benih, kebutuhan benih, menyiapkan tempat benih, mengecambahkan benih dan menyebarkan benih.

3. Penyiapan lahan

4. Penanaman

5. Perawatan (Agus Handoko, 2005)

\subsection{Analisis Pendapatan}

Kegiatan usahatani bertujuan untuk mecapai produksi dibidang pertanian. Pada akhirnya akan dinilai dengan uang yang diperhitungkan dari nilai produksi setelah dikurangi atau memperhitungkan biaya yang telah dikeluarkan.

Cahyono (1996) mengemukakan bahwa pendapatan dalam usahatani ada dua macam yaitu pendapatan kotor dan pendapatan bersih (keuntungan). Pedapatan kotor 
usahatani yaitu keseluruhan hasil atau nilai uang dari usahatani. Pendapatan kotor usahatani dikurangi dengan biaya menghasilkan atau keseluruhan jumlah korbanan, atau merupakan selisih antara harga produk ditingkat petani dengan harga pokok dikalikan dengan jumlah produk usahatani.

Sedangkan pendapatan bersih usahatani (net farm income) adalah selisih antara pendapatan kotor usahatani dengan pengeluaran total usahatani. Dikatakan pula total pendapatan diperoleh dari total penerimaan dikurangi dengan total biaya dalam suatu proses produksi (Soekartawi, 1990). Adapun biaya yang digunakan dalam proses produksi di sebut biaya produksi. Biaya produksi adalah nilai dari semua faktor produksi yang di pergunakan, baik dalam bentuk benda ataupun jasa selama proses produksi berlangsung. Biaya produksi yang di gunakan untuk bibit serta sejumlah tenaga kerja. Karena semua tanah dalam analisis ini tidak dianggap sebagai tanah sewa tanah tapi pajak di perhitungkan sebagai biaya (Soekartawi, 2001).

Mubyarto (1995) mengemukakan bahwa : Biaya produksi dapat di bagi menjadi dua yaitu biaya-biaya yang berupa uang tunai misalnya upah tenaga kerja, biaya untuk membeli bibit dan lain-lain. Biaya-biaya panen, bagi hasil, sumbangan menyangkut juga pajak-pajak (Ipeda). Besar kecilnya bagian biaya produksi yang berupa uang tunai ini sangat mempengaruhi pengembangan usaha petani. Hasil penelitian Syawal (1993) pada usaha tani rumput laut di Maros Utara dan Maros Baru menunjukkan bahwa modal dapat berpengaruh terhadap peningkatan pendapatan petani secara positip, walaupun peningkatannya tidak nyata, hal ini disebabkan besarnya modal kerja (fixed capital) yang dibutuhkan dalam kegiatan usahatanipadi ladang.

Hasil kajian yang dilakukan Sukamaluddin (1997) di Kecamatan Mappakasunggu Kabupaten Takalar menunjukkan bahwa dari segi ekonomis, usaha budidaya rumput laut dapat memberikan keuntungan yang cukup baik bagi petani-nelayan ataupun bagi investor, karena biaya operasionalnya relatif lebih rendah bila dibandingkan dengan usaha lain dan prosedur pemasarannya tidak terlalu sulit. Lebih lanjut Prawirokusumo (1990) mengemukakan bahwa penerimaan adalah perkalian produksi yang diperoleh dengan harga jual. Pernyataan ini dituliskan TR $=\mathrm{Y}$. Py dimana TR adalah total penerimaan, $\mathrm{Y}$ adalah produksi yang diperoleh dalam usahatani dan Py adalah harga $\mathrm{Y}$. Sedangkan pandapatan (keuntungan) adalah selisih antara total penerimaan dengan total biaya dengan rumus $\pi=\mathrm{TR}-\mathrm{TC}$, dimana $\pi$ adalah keuntungan (pendapatan), TR adalah total penerimaan dan TC adalah total biaya.

Biaya yang digunakan dalam proses produksi di sebut biaya produksi. Biaya produksi adalah nilai dari semua faktor produksi yang di pergunakan, baik dalam bentuk benda ataupun jasa selama proses produksi berlangsung. Biaya produksi yang di gunakan untuk bibit serta sejumlah tenaga kerja. Karena semua tanah dalam analisis ini tidak dianggap sebagai tanah sewa tanah tapi pajak di perhitungkan sebagai biaya (Soekartawi, 2001). Adapun Mubyarto (1995) mengemukakan bahwa biaya produksi dapat di bagi menjadi dua yaitu biaya-biaya yang berupa uang tunai misalnya upah tenaga kerja, biaya untuk membeli bibit dan lain-lain. Biaya-biaya panen, bagi hasil, sumbangan menyangkut juga pajak-pajak (Ipeda). Besar kecilnya bagian biaya produksi yang berupa uang tunai ini sangat mempengaruhi pengembangan usaha petani. Hasil penelitian Syawal (1993) pada usaha tani rumput laut di Maros Utara dan Maros Baru 
menunjukkan bahwa modal dapat berpengaruh terhadap peningkatan pendapatan petani secara positip, walaupun peningkatannya tidak nyata, hal ini disebabkan besarnya modal kerja (fixed capital) yang dibutuhkan dalam kegiatan usahatani rumput laut.

Selain penggolongan di atas, jenis-jenis biaya produksi dapat pula dibagi dalam biaya tetap dan biaya tidak tetap (biaya variabel). Biaya tetap adalah biaya yang besar kecilnya tidak tergantung pada besar kecilnya produksi, misalnya sewa lahan. Biaya lainnya adalah biaya tidak tetap (Variabel) adalah biaya yang besar kecil tergantung atau hubungan lansung dengan besar kecilnya produksi, misalnya biaya sarana produksi. Biaya usaha petani yang merupakan input dari biaya-biaya : sarana produksi, tenaga kerja bunga modal,biaya alat dan perkakas dan biaya-biaya lain.

\section{- Biaya Sarana Produksi}

Biaya ini dihitung untuk satu kurung waktu (periode) tertentu misalnya satu kali proses produksi. Untuk memudahkan perhitungan, dipisahkan antara biaya yang harus dibebankan dalam kurung waktu tersebut dan bukan biaya yang seharusnya di butuhkan sbagai biaya sebelumnya atau kurung waktu yang akan datang. Yang termasuk biaya yaitu pembelian selama periode, persediaan awal periode dan hutang akhit periode. Yang termasuk bukan biaya yaitu: sisa akhir periode dan hutang awal periode.

\subsection{Harga}

Harga adalah nilai suatu barang atau jasa yang diperdagangkan. Harga dapat terjadi pula apabila kekuatan tarik menarik antara produsen dan konsumen bertemu di pasar. Harga merupakan hasil akhir bekerjanya system pasar yaitu bertemunya gayagaya permintaan dan penawaran antara pembeli (konsumen) dengan penjual (produsen). Menurut Winardi (1980), mengemukakan bahwa masalah terbesar dari hasil-hasil pertanian adalah terletak pada salah satu bidang stabilitas harga terutama tendensi kearah harga-harga rendah yang timbul karena sering terdapatnya suplai produk dalam jumlah banyak di pasar. Salah satu upaya pemerintah dalam mengatasi masalah harga hasil-hasil pertanian adalah penetapan harga dasar dan harga maksimum hasil pertanian.

Menurut Soekawati (1990), bahwa kebijaksanaan harga dasar (floor price) diperlukan untuk menjaga agar harga pasar pada saat panen tidak jauh menurun ke bawah dari yang seharuanya diterima oleh produsen dan diupayakan agar harga pasar minimal sama dengan harga dasar. Sebaliknya harga maksimum (ceiling price) tetap diperlukan khususnya pada musim paceklik saat persediaan prodksi terbatas, sehingga dengan demikian harga dikatakan relatif efektif apabila harga pasar berada diantara harga dasar dan harga maksimum, maka baik konsumen maupun produsen masingmasing tidak dirugikan.

Pada saat harga hasil-hasil pertanian kecenderungan untuk mengalami perubahan relatif besar. Harga dapat mencapai tingkat yang lebih tinggi sekali pada suatu masa dan mengalami kemerosotan pada masa berikutnya. Ketidakstabilan tersebut disebabkan oleh permintaan dan penawaran mengalami perubahan. Produksi pertanian di daerah pedesaan pada umumnya bersifat musiman. Gejala semacam ini mengakibatkan pendapatan petani juga bersifat musiman. Keadaan ini dilukiskan diatas, mengakibatkan petani selalu berada dipihak yang lemah dalam memasarkan hasil pertaniannya. Disamping itu barang yang dihasilkan di daerah relatif banyak 
dibandingkan dengan permintaan yang ada, akibatnya harga yang terjadi dipedesaan relatif rendah.

Memenuhi permintaan konsumen yang semakin meningkat maka produksi yang dihasilkan petani selalu sama dengan jumlah barang yang diminta oleh konsumen bila dikehendaki harga pasaran tetap. Bila terjadi demikian misalnya jumlah barang yang diminta lebih banyak barang dari yang disediakan maka harga akan naik. Begitu pula sebaliknya bila terjadi kelebihan produksi yang disediakan (over suplai), maka akan cenderung menurun. Hal ini sesuai hukum penawaran dan permintaan yang berbunyi sebagai berikut: Kalau produk itu langka terdapat di pasaran sedang permintaan akan produk tersebut banyak, maka harga produk itu meningkat. Sebaliknya kalau produk itu membanjiri pasaran sedang permintaan tidak mengalami perubahan, maka harga pokok itu akan menurun (Soekartawi, 1990).

Turun naiknya harga suatu barang dapat mempengaruhi sistem harga dan gejala ekonomi. Sistem pembentukan harga merupakan gejala ekonomi yang sangat berhubungan dengan perilaku petani baik sebagai produsen maupun konsumen. Sehubungan dengan itu A.M. Saefuddin (1982), mengatakan bahwa pendapatan petani sangat labil, sewaktu waktu bisa lebih besar dan bisa pula lebih kecil, demikian seterusnya. Bahwa perubahan hasil pertanian itu sangat tergantung kepada keadaan penawaran dan permintaan. Perubahan-perubahan yang terjadi pada permintaan atau penawaran atau pada kedua-duanya akan menyebabkan terjadinya perubahan harga dan keadaan pasar serta aktivitas pemasaran akan mengalami suatu perubahan.

Mengukur besar kecilnya harga yang terjadi sebagai akibat perubahan jumlah barang, dapat dipakai konsep elastistas jumlah (fleksibilitas harga) dimana harga menjadi variable bebas. Konsep ini menyatakan perbandingan antara persentase perubahan harga dengan persentase perubahan jumlah barang. Dalam menuliskan angka elastistas jumlah ini sering kita melihat tanda negative, ini menunjukkan harga tersebut dan sebaliknya jumlah barang turun diikuti oleh kenaikan harga barang tersebut.

\subsection{Analisis BEP}

Dengan analisis Break Even Point (BEP) petani dapat merencanakan segala sesuatu karena sabagai berikut:

1. Dapat menghitung berapa produk maupun penerimaan yang harus dicapai agar petani memperoleh keuntungan atau keuntungan margin.

2. Dapat menghitung berapa harga jual agar petani untung di atas total biaya produksi atau untung dari total biaya produksi yang telah dikeluarkan petani. (Ken Suratiyah, 2006).

\section{METODE PENELITIAN}

\subsection{Waktu dan Lokasi Penelitian}

Penelitian ini dilaksanakan di Desa Lapandewa Kaindea Kecamatan Lapandewa Kabupaten Buton Selatan, mulai bulan Mei sampai dengan Juni 2017. 


\subsection{Waktu dan Lokasi Penelitian \\ Teknik Penentuan Sampel}

Populasi dari penelitian ini adalah petani yang melakukan usahatani bawang merah yang ada di Desa Lapandewa Kaindea Kecamatan Lapandewa Kabupaten Buton Selatan adalah 32 orang, sehingga dilakukan metode sensus dengan mengambil seluruh responden yang berjumlah 32 orang.

\subsection{Teknik Pengambilan Data}

Dalam penelitian ini alat pengumpulan data terdiri atas :

1. Menggunakan kuesioner atau angket.

2. Observasi.

3. Studi perpustakaan.

\subsection{Variabel yang diamati}

Variabel yang diamati dalam penelitian ini adalah:

1. Identitas responden yang meliputi umur, tingkat pendidikan, jumlah tanggungan keluarga, pengalaman berusahatani bawang merah.

2. Keadaan usahatani meliputi luas lahan, penerimaan, biaya, produksi, harga dan pendapatan bawang merah.

\subsection{Teknik Analisa Data}

Berdasarkan rumusan masalah dan hipotesis dalam penelitian ini, maka data yang telah dikumpulkan selanjutnya dianalisis deskriptif kualitatif dan kuanlitatif. Untuk membuktikan pendapatan usahatani bawang merah yang diperoleh dari perhitungan sebagai berikut:

3.5.1. Mengetahui besarnya biaya yang dikeluarkan oleh petani, dapat digunakan formulasi: $\mathbf{T C}=\mathbf{T F C}+\mathbf{T V C}($ Ken Suratiyah, 2006)

\section{Keterangan:}

$\mathrm{TC}=$ Total cost (biaya total) satuannya (Rp)

$\mathrm{TFC}=$ Total fixed cost (biaya tetap total) satuannya (Rp)

$\mathrm{TVC}=$ Total variabel cost (biaya variable) total satuannya $(\mathrm{Rp})$

3.5.2. Menghitung besarnya penerimaan yang diperoleh petani bawang merah adalah :

TR = P x Q (Ken Suratiyah, 2006)

\section{Keterangan :}

NI = Net Income (pendapatan bersih) satuannya (Rp)

$\mathrm{TR}=$ Total Revenu (penerimaan total) satuannya $(\mathrm{Rp})$

$\mathrm{TC}=$ Total cost (biaya total) satuannya ( $\mathrm{Rp})$

$\mathrm{P} \quad=$ Price (harga jual produksi) satuannya $(\mathrm{Rp} / \mathrm{kg})$

$\mathrm{Q}=$ Kuantitas (jumlah produksi) satuannya ( $\mathrm{Rp} / \mathrm{kg}$ ) 
3.5.3. Menghitung besarnya pendapatan yang diperoleh petani bawang merah adalah : $\mathbf{I}=\mathbf{R}-\mathbf{T C} \quad$ (Ken Suratiyah, 2006)

3.5.4. Sedangkan untuk BEP Penerimaan adalah

FC

BEP Penerimaan $=$

(Ken Suratiyah, 2006)

\subsection{Definisi Operasional}

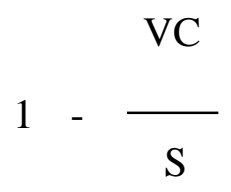

a. Petani adalah orang yang mengusahakan tanaman bawang merah.

b. Produksi adalah jumlah atau banyaknya bawang merah yang dihasilkan oleh petani (Kw. atau Kg)

c. Tenaga kerja adalah jumlah curahan tenaga kerja pada usahatani bawang merah (Rp/HOK).

d. Harga jual adalah harga bawang merah yang berlaku ditingkat petani ( $\mathrm{Rp} / \mathrm{kg}$ atau $\mathrm{Rp} / \mathrm{Kw}$ )

e. Biaya usahatani bawang merah adalah keseluruhan biaya yang dikeluarkan oleh petani bawang merah (Rp).

f. Penerimaan usahatani bawang merah adalah produksi bawang merah dikali dengan harga jual ditingkat petani dalam satuan (Rp)

g. Pendapatan adalah jumlah penerimaan dikurangi biaya yang dikeluarkan petani dalam satu kali panen (Rp)

h. BEP Penerimaan adalah biaya tetap dibagi satu kurang biaya variabel dibagi penerimaan $(\mathrm{Rp})$.

\section{HASIL PENELITIAN}

\subsection{Identifikasi petani responden}

Identifikasi petani responden merupakan latar belakang keadaan responden yang menentukan bagi suatu perubahan variabel dalam penelitian. Adapun identitas petani responden yang akan diuraikan sebagai berikut:

\subsubsection{Umur}

Tingkat umur menggambarkan keadaan, kemampuan fisik dan pikiran petani dalam mengelola usaha budidaya agar senantiasa berhasil. Disamping itu umur memberikan identifikasi fisik, dimana umur tua memiliki kemampuan yang kurang jika dibandingkan dengan umur yang muda. Dalam penelitian ini petani responden dikelompokkan berdasarkan kategori usia produktif dan non produktif. Untuk lebih jelasnya mengenai hal ini dapat dilihat pada tabel 2 berikut.

Tabel 2. Pengelompokan responden berdasarkan kategori usia di Desa Lapandewa Kaindea , 2017

\begin{tabular}{llll}
\hline No. & $\begin{array}{l}\text { Kategori Usia } \\
\text { (Tahun) }\end{array}$ & $\begin{array}{l}\text { Jumlah } \\
\text { Responden } \\
(\text { Orang })\end{array}$ & $\begin{array}{l}\text { Prosentase } \\
(\%)\end{array}$ \\
\hline 1. & Produktif $(30-54)$ & 18 & 56,25 \\
2. & Non Produktif $(55-58)$ & 14 & 43,75 \\
\hline
\end{tabular}



Jumlah
32
100,00

Berdasarkan tabel tersebut di atas, terlihat bahwa petani responden umumnya masih dalam kategori usia produktif sehingga kondisi ini dapat mengidentifikasikan bahwa sesungguhnya petani responden cenderung mempunyai sikap dan pola pikir yang inovatif, sehingga mereka mengembangkan usahataninya kearah yang lebih baik.

\subsubsection{Pendidikan}

Faktor pendidikan adalah sangat menentukan terhadap pengetahuan petani untuk melakukan usahataninya yang baik, sebab cepat atau lambatnya perubahan dan sikap pola pikir sesorang banyak dipengaruhi oleh tingkat pendidikannya. Menurut Suharjo dan Dahlan Patong (1973), mengemukakan bahwa pendidikan pada umumnya dapat mempengaruhi cara berpikir petani. Pendidikan yang dimaksud dalam penelitian ini adalah pendidikan formal yang pernah diikuti oelh petani responden. Untuk lebih jelasnya dapat dilihat pendidikan yang pernah diikuti oleh 32 responden tabel 3 pada halaman berkitunya

Tabel 3. Pengelompokan responden berdasarkan tingkat pendidikan formal di

Desa Lapandewa Kaindea , 2017

\begin{tabular}{|l|l|l|l|}
\hline No. & Tingkat Pendidikan & $\begin{array}{l}\text { Jumlah } \\
\text { Responden } \\
\text { (Orang) }\end{array}$ & $\begin{array}{l}\text { Prosentase } \\
(\%)\end{array}$ \\
\hline 1. & Tamat SD & 14 & 43,75 \\
2. & Tamat SMP/SLTP & 15 & 46,88 \\
3. & Tamat SMU/SLTA & 3 & 9,38 \\
\hline & Jumlah & 32 & 100,00 \\
\hline
\end{tabular}

Pada tabel 3 diatas, umumnya petani responden mempunyai jenjang pendidikan formal hanya pada tingkat SMU hanya sekitar 9,38\% (3 orang), mayoritas berpendidikan SD dan SMP. Hal ini berpengaruh kepada pengelolaan usahataninya, yang berarti petani yang tamat SMU cenderung untuk meningkatkan pendapatan usahataninya dibanding dengan yang tamat SD dan SMP. Kondisi seperti ini menunjukkan bahwa para petani cukup paham tentang pentingnya pendidikan, untuk itu perlu adanya pembinaan baik melalui kursus-kursus dan penyuluhan yang lebih intensif agar pengetahuan dan wasasan para petani dapat lebih berkembang untuk menjadi petani yang produktif dan profesional.

\subsubsection{Pengalaman Berusahatani}

Pengalaman berusahatani adalah sangat menentukan bagi keberhasilan petani dalam memperoleh hasil usahataninya dalam jumlah yang memadai, karena dengan pengalaman yang dialami para petani dalam berusahatani sebelumnya secara tidak langsung akan merubah sikap petani untuk berusahatani yang baik. Hal ini disebabkan oleh adanya peningkatan hasil produksi pertaniannya dalam setiap musim panen.

Pengalaman berusahatani adalah pendidikan non formal yang diperoleh petani melalui kegiatan yang pernah atau telah dialaminya. Pengalaman berusahatani dapat menjadi suatu bahan pertimbangan atau perbandingan dalam suatu proses pengambilan suatu kebijakan atau keputusan terhadap pengelolaan usahatani yang digelutinya.

Secara umum dapat diasumsikan bahwa semakin lama pengalaman petani dalam berusahatani, maka petani tersebut akan semakin matang dan mantap dalam memperhitungkan masalah-masalah atau resiko dan ketidakpastian yang mungkin akan terjadi di lapangan sehubungan dengan pengelolaan usahataninya. Oleh karena itu, pengalaman tersebut oleh petani dijadikan suatu pendidikan yang sangat berharga dalam bidang usaha pertanian khususnya pertanian bawang merah. Dengan demikian berdasarkan pengalaman yang dialami oleh petani, maka untuk kelanjutan kegiatan dalam bercocok tanam 
di bidang pertanian bawang merah, dilakukan beberapa kelompoktani yang nantinya dapat meringankan beban petani. Berdasarkan pengalaman berusahatani, maka petani responden dapat dikelompokkan seperti pada tabel 4 berikut.

Tabel 4. Pengelompokan responden berdasarkan pengalaman berusahatani di Desa Lapandewa Kaindea , 2017

\begin{tabular}{lllc}
\hline No. & $\begin{array}{l}\text { Lamanya } \\
\text { Berusahatani } \\
\text { (Tahun) }\end{array}$ & $\begin{array}{l}\text { Jumlah Responden } \\
\text { (Orang) }\end{array}$ & $\begin{array}{l}\text { Presentase } \\
(\%)\end{array}$ \\
\hline 1. & $5-12$ & 21 & 65,62 \\
2. & $13-25$ & 11 & 34,38 \\
\hline & Jumlah & 32 & 100,00 \\
\hline
\end{tabular}

Tabel 4 diatas, menunjukkan bahwa secara umum petani responden telah mempunyai pengalaman yang rendah dalam berusahatani, sehingga kondisi ini tentunya diharapkan dapat memberikan pengaruh negatif bagi perkembangan kegiatan usahatani yang dikelolah oleh petani responden yang ada di Desa Lapandewa Kaindea.

\subsection{Analisis Pendapatan dan BEP Penerimaan Usahatani Bawang Merah}

Masalah harga dalam kegiatan usahatani merupakan faktor perangsang dalam produksi. Jika harga bawang merah naik akan memberikan kontribusi pendapatan yang memadai bagi petani, sehingga para petani akan terdorong untuk meningkatkan produksinya. Sebaliknya jika harga bawang merah turun motivasi petani untuk meningkatkan produksinya kurang disebabkan karena harga dari usahataninya tidak memberikan kontribusi pendapatan yang memadai bagi petani. Oleh karena itu masalah harga ini untuk menjaga kestabilannya sangat penting sebagai salah satu alat kebijaksanaan untuk menggairahkan para petani dalam berproduksi. Ketidakstabilan harga atau terjadinya fluktuasi harga akan mempengaruhi tingkah laku petani dalam merencanakan produksinya.

Keadaan fluktuasi harga sering dialami oleh para petani sehingga pada saat-saat tertentu dapat kita temukan harga hasil usahatani kadang-kadang naik dan kadangkadang turun. Keadaan fluktuasi harga ini dapat pula terjadi pada usahatani bawang merah di Desa Lapandewa kaindea. Fluktuasi harga pada prinsipnya mempunyai pengaruh pada penggunaan faktor produksi yang dimaksud disini menyangkut luas lahan, penggunaan pupuk dan produksi.

Untuk menganalisis lebih jauh biaya dan penerimaan usahtani bawang merah di Lapandewa Kaindea dapat diuraikan sebagai berikut.

\subsubsection{Analisis Produksi, Penerimaan, Biaya dan Pendapatan Usahatani Bawang Merah}

\subsubsection{Produksi}

Produksi yang dimkasud adalah jambu mete yang diperoleh petani responden dalam jangka waktu selama satu musim panen. Mengenai tingkat produksi bawang merah petani responden dapat dilihat pada tabel 5.

Tabel 5. menunjukkan bahwa sebagian besar responden $(78,16 \%)$ atau 25 orang dengan produksi antara $300-650 \mathrm{~kg}$ dengan produksi rata-rata $527 \mathrm{~kg}$. Hal ini menunjukkan bahwa kecenderungan petani untuk memperoleh produksi yang lebih besar. 
Produksi yang dihasilkan oleh petani responden itu langsung dijual untuk memperoleh uang tunai, ini diperlukan untuk memenuhi kebutuhan sehari-hari, dan ada juga petani yang menyimpan bawang merah dan menjual pada saat harga lebih tinggi. Untuk mengetahui sejauh mana tingkat produksi bawang merah pada Desa Lapandewa kaindea Kecamatan Lapandewa Kabupaten Buton Selatan dapat dilihat pada tabel dibawah ini.

Tabel 5. Data Jumlah dan Prosentase Petani Responden Berdasarkan Keadaan Tingkat Produksi Bawang Merah di Desa Lapandewa Kaindea, 2017.

\begin{tabular}{llll}
\hline $\begin{array}{l}\text { Tingkat Produksi } \\
(\mathrm{kg})\end{array}$ & $\begin{array}{l}\text { Jumlah } \\
\text { Responden } \\
(\text { Orang })\end{array}$ & $\begin{array}{l}\text { Prosentase } \\
(\%)\end{array}$ \\
\hline 1. & $300-650$ & 25 & 78,16 \\
2. & $651-1.000$ & 8 & 21,84 \\
\hline & Jumlah & 32 & 100,00 \\
\hline
\end{tabular}

\subsubsection{Nilai Penerimaan}

Nilai produksi adalah jumlah produksi yang dihasilkan pada musim tanam. Nilai produksi (penerimaan) sangatlah menentukan dalam memperoleh pendapatan usaha tani. Nilai produksi yang dimaksud dalam penelitian ini adalah jumlah produksi yang dihasilkan dikalikan dengan harga jual dalam satu kali musim panen yang dinyatakan dalam rupiah. Mengenai tingkat nilai penerimaan bawang merah petani responden dapat dilihat pada Tabel 6.

Tabel 6. menunjukkan bahwa sebagian besar petani responden yang nilai penerimaan antara Rp. 1.760.000,- - Rp. 4.640.000,- atau (71,88\%) dibandingkan dengan penerimaan antara Rp. . 4.640.001,- - Rp. 6.400.000,- atau $(28,12 \%)$ dengan rata-rata penerimaan Rp. 3.794.500,-. Hal ini menunjukkan bahwa produksi yang dihasilkan oleh petani responden langsung dijual untuk memperoleh pendapatan sebagai usaha pemenuhan kebutuhan seharihari maupun membuka sumber usaha lain. Untuk lebih jelasnya penerimaan yang diperoleh petani bawang merah pada lokasi penelitian dapat dilihat pada tabel dibawah ini:

Tabel 6. Data Jumlah dan Prosentase Petani Responden Berdasarkan Nilai Penerimaan Bawang Merah di Desa Lapandewa Kaindea, 2017.

\begin{tabular}{llll}
\hline No. & $\begin{array}{l}\text { Nilai Penerimaan } \\
(\mathrm{Rp})\end{array}$ & $\begin{array}{l}\text { Jumlah } \\
\text { Responden } \\
\text { (Orang) }\end{array}$ & $\begin{array}{l}\text { Prosentase } \\
(\%)\end{array}$ \\
\hline 1. & $7.360 .000-15.180 .000$ & 23 & 71,88 \\
2. & $15.180 .001-23.000 .000$ & 9 & 28,12 \\
\hline & Jumlah & 32 & 100,00 \\
\hline
\end{tabular}

\subsubsection{Biaya Produksi}

Biaya produksi adalah semua pengeluaran biaya produksi dinyatakan dengan uang. Biaya yang dimaksud dalam penelitian ini adalah keseluruhan biaya yang dikeluarkan oleh petani selama melakukan kegiatan usahatani. Dalam hal ini biaya produksi yang dikeluarkan adalah biaya variabel dan biaya tetap dalam kegiatan usahatani bawang merah. Untuk mengetahui biaya produksi bawang merah dapat dilihat pada tabel 7 halaman berikutnya.

Tabel 7. Rata-rata biaya usahatani bawang merah Desa Lapandewa Kaindea, 2017

\begin{tabular}{ll}
\hline No. Uraian & Jumlah \\
$(\mathrm{Rp})$
\end{tabular}




\begin{tabular}{|c|c|c|}
\hline 1. & Biaya Variabel (VC) & 470.313,- \\
\hline & Benih & \\
\hline 2. & Biaya Tetap (FC) & $42.188,-$ \\
\hline & Penyusutan Alat & \\
\hline 3. & Biaya Total $(\mathrm{TC})=\mathrm{VC}+\mathrm{FC}$ & 500 \\
\hline
\end{tabular}

Tabel 7. menunjukkan bahwa petani responden yang usahatani bawang merah sebagaimana pada lampiran 3 diperoleh rata-rata Rp. 512.500,- dengan luas lahan rata-rata 0,14 ha dimana biaya yang dikeluarkan adalah biaya benih dan penyusutan alat. Hal ini menunjukkan bahwa besar kecilnya biaya yang dikeluarkan dapat mempengaruhi besar kecilnya jumlah perolehan pendapatan bersih utama.

4.2.1.4 Pendapatan

Pendapatan yang dimkasud dalam penelitian ini adalah selisih antara penerimaan dengan seluruh biaya produksi, penyusutan alat pada satu kali proses produksi dalam setahun. Kriteria yang dikemukakan Sejogyo dalam Muhude (1996), bahwa pendapatan untuk wilayah pedesaan standart kebutuhan minumnya rata-rata Rp. 144.000,- - Rp. 192.000,- pertahun, tergolong pendapatan yang rendah.

Pendapatan yang diperoleh adalah penerimaan dikurangi biaya produksi yang digunakan selama musim panen terakhir. Untuk lebih jelasnya mengenai pendapatan petani responden dapat dilihat pada tabel 8.

Tabel 8. Pendapatan Petani bawang merah Desa Lapandewa Kaindea, 2017

\begin{tabular}{llll}
\hline No. & $\begin{array}{l}\text { Tingkat Pendapatan } \\
(\mathrm{Rp})\end{array}$ & $\begin{array}{l}\text { Jumlah } \\
\text { Responden } \\
(\text { Orang) }\end{array}$ & $\begin{array}{l}\text { Prosentase } \\
(\%)\end{array}$ \\
\hline 1. & $2.430 .000-4.070 .000$ & 24 & 75,00 \\
2. & $4.070 .001-5.710 .000$ & 8 & 25,00 \\
\hline & Jumlah & 32 & 100,00 \\
\hline
\end{tabular}

Rata-rata pendapatan usahatani bawang merah Desa Lapandewa Kaindea, 2017

\begin{tabular}{llc}
\hline No. & Uraian & $\begin{array}{l}\text { Jumlah } \\
(\mathrm{Rp}, \mathrm{kg})\end{array}$ \\
\hline 1. & Penerimaan & $\mathbf{3 . 7 9 4 . 5 0 0 , -}$ \\
& a. Produksi & $237,16 \mathrm{~kg}$ \\
& b. Harga & $16.000 / \mathrm{kg}$ \\
2. & Biaya Total (TC) $=$ VC + FC & $\mathbf{5 1 2 . 5 0 0 , -}$ \\
3. & Pendapatan (Ni atau I) & $\mathbf{R p . 3 . 2 8 2 . 0 0 0 , -}$ \\
\hline
\end{tabular}

Tabel 8 menunjukkan bahwa pendapatan bersih yang diterima petani responden di lokasi penelitian dirasakan cukup untuk memenuhi kebutuhan hidup minimum sebab menurut kriteria yang dikemukakan Sejogyo dalam Muhude (1996), dikatakan bahwa untuk wilayah pedesaan standart kebutuhan minimumnya jika dinilai dengan uang rata-rata Rp. 144.000,- Rp. 192.000,- pertahun, tergolong pendapatan yang rendah. Sedangkan Surat Keputusan Gubernur Sulawesi Tenggara Nomor 36 Tahun 2016 tentang Upah minimum Regional (UMR) Sulawesi Tenggara Tahun 2017 sebesar Rp. 2.002..625,- atau naik 8\% dari Tahun 2016 sebesar Rp. 1.850.000,-. Berdasarkan dari kriteria tersebut, maka dapat disimpulkan 
bahwa petani responden di lokasi penelitian sudah berada di atas garis kemiskinan atau dengan kata lain, petani bawang merah dapat terpenuhi kebutuhan hidupnya untuk memenuhi anggota keluarga.

Untuk rata-rata pendapatan yang diterima petani responden usahatani bawang merah di Desa Lapandewa Kaindea Kecamatan Lapandewa adalah :

$$
\begin{aligned}
\mathrm{Ni} & =\mathrm{TR}-\mathrm{TC} \\
\mathrm{Ni} & =\text { Rp. 3.794.500,- }- \text { Rp. 512.500,- } \\
& =\text { Rp. 3.282.000,- }
\end{aligned}
$$

Dari angka ini menunjukkan bahwa pendapatan bersih yang diterima petani responden di lokasi penelitian dirasakan cukup untuk memenuhi kebutuhan hidup minimum, hal ini pula diperkuat dengan pendapat Sejogyo dalam Muhude (1996), dikatakan bahwa Surat Keputusan Gubernur Sulawesi Tenggara Nomor 36 Tahun 2016 tentang Upah minimum Regional (UMR) Sulawesi Tenggara Tahun 2017 sebesar Rp. 2.002..625,-, ini tegolong sedang dibandingkan di provinsi lain. Di lain pihak petugas penyuluh lapangan mengatakan bahwa pada daerah lokasi penelitian ini rata-rata petani yang mengusahakan tanaman bawang merah. Hal ini pula ini diperkuat pendapat Cahyono (1996) mengemukakan bahwa pendapatan dalam usahatani ada dua macam yaitu pendapatan kotor dan pendapatan bersih (keuntungan). Pedapatan kotor usahatani yaitu keseluruhan hasil atau nilai uang dari usahatani. Pendapatan kotor usahatani dikurangi dengan biaya menghasilkan atau keseluruhan jumlah korbanan, atau merupakan selisih antara harga produk ditingkat petani dengan harga pokok dikalikan dengan jumlah produk usahatani.

\subsubsection{Analisis BEP Penerimaan Usahatani Bawang Merah}

Anaisis BEP penerimaan bawang merah adalah untuk menghitung jumlah penerimaan yang diperoleh petani dalam satu kali musim panen yang dipengaruhi oleh biaya tetap, biaya variabel dan penerimaan. Untuk mengetahui berapa jumlah BEP penerimaan yang diperoleh petani bawang merah di lokasi penelitian adalah:

FC

BEP Penerimaan $=$

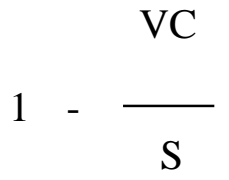

1.350.000,-

BEP Penerimaan $=$ 


$$
1-\frac{15.050 .000,-}{121.424 .000,-}
$$

\section{BEP Penerimaan = Rp. 1.541.000,-}

Dari hasil perhitungan diatas menunjukan bahwa usahatani bawang merah di Desa Lapadewa kaindea Kecamatan Lapandewa mengalami break even point atau tidak untung dan tidak rugi jika penerimaan yang diperoleh pada tingkat petani sebesar Rp. 1.541.000 per musim tanam. Dengan demikian sangat beralasan disebabkan mayoritas responden petani di daerah penelitian bermata pencaharian bertani bawang merah, dengan produksi rata-rata $237,16 \mathrm{~kg} / \mathrm{ha}$. Ini menunjukan bahwa petani bawang merah telah mengikuti anjuran yang dilakukan oleh penyuluh lapangan. Hal ini pula diperkuat pernyataan oleh salah satu petugas lapangan yang mengatakan bahwa rata-rata petani didaerah penelitian adalah petani bawang merah yang mempunyai keinginan untuk selalu mau melakukan usahatani dengan baik agar memperoleh produksi yang maksimal agar mendapatkan pendapatan yang lebih optimal serta adanya keinginan petani memperoleh informasi tentang varietas bawang merah yang dapat meningkatkan hasil usahataninya (Hasil wawancara dengan Petugas Penyuluh Kecamatan Lapandewa, Rajab, SP.).

\section{KESIMPULAN DAN SARAN}

\subsection{Kesimpulan}

Berdasarkan uraian hasil penelitian, maka dapat disimpulkan sebagai berikut:

1. Rata-rata pendapatan yang diterima petani bawang merah adalah Rp. 3.282.000,dengan rata-rata luas lahan garapan antara 0,14 ha.

2. BEP Penerimaan bawang merah di lokasi penelitian adalah Rp. 1.541.000,- per musim tanam.

\subsection{Saran} berikut :

Dari kesimpulan hasil penelitian tersebut, maka dapat disarankan adalah sebagai

1. Petani bawang merah di Desa Lapandewa Kaindea perlu memberdayakan lembaga pemasaran yang berbentuk Koperasi Unit Desa, sehingga menjadi lembaga pemasaran yang dapat menanpung hasil usahatani bawang merah serta dapat berfungsi untuk dapat mnciptakan kestabilan harga.

2. Pemerintah daerah terutama ditingkat kabupaten perlu menetapkan peraturanperaturan yang berhubungan dengan sistem pemasaran bawang merah terutama penetapan harga dasar. 


\section{DAFTAR PUSTAKA}

Agus Handoko, 2005. Ilmu Usahatani. PT Bina Aksara. Jakarta. Anwas Adiwilaga, 1982. Ilmu Usahatani. Alumni. Bandung.

Badan Pusat Statistik Kabupaten Buton, 2016-2017. Buton Dalam Angka 2016-2017. Kantor Badan Pusat Statsitik Kabupten Buton. Pasarwajo.

Dinas Pertanian Kabupaten Buton, 2017. Laporan Tahunan Dinas Pertanian Kabupaten Buton Selatan. Batauga.

G. Kartasapoetra dkk, 1992. Marketing Produk Pertanian dan Industri yang Diterapkan di Indonesia. PT. Bina Aksara. Jakarta.

Ken Suratiyah, 2006. Ilmu Usahatani. PT. Remaja. Jakarta.

Irawan, 2003. Azas-Azas Manajemen Produksi. Bumi Aksara. Jakarta.

Irawan et al, 2006. Menggerakan dan Membangun Pertanian. CV. Yasaguna, Jakarta.

Richard, H Letwich, 1984. Mikro Ekonomi. Diterjemahkan oleh St. Dianjung. PT. Bina Aksara. Jakarta.

Purwanti dan Asga, 1990. Agrobisnis Tanaman Hias. Peneribit Swadaya. Jakarta.

Prawirokusmo, 1990. Analisis Usahatani Padi sawah. Peneribit Surabaya.

Saefuddin A.M., 1982. Pengkajian Pemasaran Komoditi. Diktat Pascasarjana Institut Pertanian Bogor. Bandung.

Sundstrom, 1982. Manajemen Produk Modern. Fakultas Ekonomi Universitas Indonesia. Jakarta.

Soekartawi, 1990. Teori Ekonomi Produksi dengan Pokok Bahasan, Analisis Fungsi Cobb-Douglas. Rajawali Press. Jakarta.

Cobb---, 2001. Agribisnis Teori dan Aplikasinya Cetakan ke-6. PT. Raja Grafindo Persada. Jakarta.

Wijayani., 2000. Dasar-Dasar Manajemen Umum. Pustaka Dian. Jakarta.

Winardi, 1980. Azas-Azas Marketing. Penerbit Alumni. Bandung. 